\title{
Ramses II in Face of Asian Deities: Some New Considerations
}

\author{
Evan Edward*
}

Guidance Department, Tourism \&amp; Hotels, Pharaohs academy, Giza, Egypt.

\section{ARTICLE INFO}

Keywords:

Asian; Deities;

Ramses II; New

Kingdom.

(JAAUTH)
Vol. 18, No. 2,
(2020),
pp.57-75.

\begin{abstract}
Ancient Egyptian religion had embraced many foreign gods and goddesses. Perhaps the reason behind this is the expansion made by the kings of the New kingdom, conquering many countries that include different civilizations and cultures from the ancient Egyptian civilization. Also, the military expansion made by the kings of the New Kingdom to the Egyptian borders which became an Empire. During the reign of king Ramses II, who had ascended the throne of Egypt after prominent kings, was able to establish a powerful empire. It is worth mentioning that king Ramses II who was always proud by his victories and military campaigns, was interested in showing himself humiliating all his enemies through reliefs, statues. So, art during king Ramses II played a vital role in reflecting this power and domination. This paper aims to shed light on the representations of king Ramses II with the foreign deities. It investigates the reasons behind king Ramses II's choice of these gods and goddesses to be represented. The paper discusses these gods and goddesses' costumes, positions, emblems. The paper concluded that king Ramses II is considered one of the most Egyptian kings who appeared in various representations with foreign gods, and artists tried hard to show these gods and goddesses with an Egyptian appearance that is in line with the Egyptian king while preserving the foreign tendency of each god. The artists had put a system during the reign of king Ramses II; they managed to Egyptianize all foreign deities. This means that all Asian and Palestinian gods and goddesses represented with king Ramses II were in Egyptian features while keeping their ethnicity.
\end{abstract}

\section{Introduction}

The existence of foreign gods and goddesses in ancient Egypt dated back to Old Kingdom, exactly when Egypt had set up relations with its neighbors. Although the ancient Egyptian society was open to all cultures and civilizations, it kept its Egyptian gods and goddess far from any change or effect. ${ }^{1}$ The Egyptian borders from south was Nubia which Nubian gods and goddess were shown in the Egyptian pantheon with Egyptian features and Nubian's ethnicity.

Egypt's border from West was Libya where god Ha and Ash were depicted in Egyptian civilization. They were represented like the Egyptian gods with short kilt holding

* evan.edward2013@hotmail.com

1 Keiko, K., Syro-Palestinian deities in New Kingdom Egypt: The hermeneutics of their existence. Oxford, 2009, p.19-26.

57 I P g g e 
long staff. Finally, from East there was a diversity in culture and civilization. Egypt could absorb all these cultures and Egyptianize all foreign features of these gods and goddess to suit Egyptian traditions. .

The New Kingdom of Egypt was the flourishing period on all levels: political, art, social. The kings of the New Kingdom after Hyksos repulsing had followed a new strategic which is known as 'attack is better than defense', which helped them expand Egypt's borders to Euphrates River from North and third cataract from south. This vast Egyptian Empire needed a powerful king to submit his enemies under his control. ${ }^{3}$

King Ramses II was one of these kings who could expand his power on all states outside Egypt. On the artistic view Ramses II had adopted a plan to Egyptianize all foreign gods and goddesses. Artists during his reign depicted the foreign gods in Egyptian manner. For example, Ramses II was represented with Syrian goddess Anat in pure Egyptian features; Anat had appeared as an Egyptian lady with tall tight dress and a crown with all Egyptian features even the titles.

King Ramses II was represented in face of many foreign gods and goddess such as Anat, Ashtart, and Baal. The researcher will display these representations of Ramses II with these foreign gods and goddess in some new considerations. The researcher will try to clarify the combination between the Egyptian features that were added to these foreign gods with some foreign ethnicity.

2 Schneider, T, Foreign Egypt: Egyptology and the concept of cultural appropriation. Ägypten und Levante 13, 2003, p.155 - 161; Wolfgang, H., 1966 Zum Auftreten fremder Götter in Ägypten. Oriens Antiques, p. 1

3 Cornelius, I., From Bes to Baal: Religious Interconnections between Egypt and the East. In: Pharaoh's Land and Beyond: Ancient Egypt and its Neighbours, P.P.Creasman \& R.H. Wilkinson (eds.). 209-217; Lipinski, E., Egypto-Canaanite iconography of Reshef, Bacal, Horon, and Anat. Chronique d'Egypte 1996, p. 251 -260; Stadelmann, R., 1967 Syrisch-Palastinensische Gottheiten in Ägypten. Probleme der Ägyptologie 5. Leiden: Brill; Albright, W.F. 1939. 'Astarte Plaques and Figurines from Tell Beit Mirsim', Mélanges Syriens offerts à Monsieur René Dussaud, Librairie Orientaliste Paul Geuthner, Paris, p. 107-120; Albright, W.F. 1939. 'Astarte Plaques and Figurines from Tell Beit Mirsim', Mélanges Syriens offerts à Monsieur René Dussaud, Librairie Orientaliste Paul Geuthner, Paris, p. 107-120; 


\section{Goddess Anat ${ }^{4}$}

Doc. 1

Owner of Piece: Relief of king Ramses II with Goddess Anat. ${ }^{5}$

Location: Relief of Ramses II and the Goddess Anat, Tanis, Egypt.

Piece no: Brooklyn Museum, 2.5.1.2 B ${ }^{6}$

Date: New Kingdom, reign of king Ramses II

\section{Doc 1A}

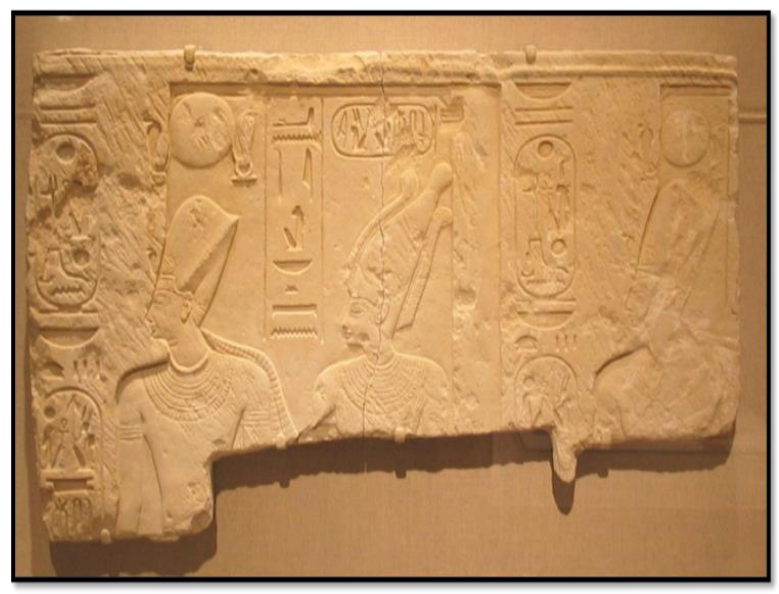

Doc 1A: The scene represents Goddess Anat with king Ramses II. Anat appears wearing the Atef crown of Osiris, and she appears with a broad collar. Figure of king in combined raised and sunk relief and preserved only to torso. ${ }^{7}$ This representation of King Ramses II with Anat was extracted from Tanis temple, but it looks like blocks from a private tomb at Saqqara showing seated pair statues of Ramses II with a deity in a similar combination of raised and sunk relief. The artist tried hard to Egyptianize the foreign goddess Anat by adding the Egyptian crown, necklace and Egyptian facial features. ${ }^{8}$

\footnotetext{
${ }^{4}$ The name Anat (contrary to some Ugaritologists who from time to time think up an etymology based on her character) is the same as the Mri anAt, the goddess of Hana, Hana being the name of an Amorite nomadic group. Hebrew and Phoenician name of Anat is ענת, 'Anōt; Ugaritic 'nt; Greek Ava $\theta$, Anath; Egyptian Antit, Anit, Anti, or Anant is a major northwest Semitic goddess. Her epithets are btit, usually rendered 'virgin', st, 'lady' and ybmt I imm, and 'widow of the peoples' or 'widow of the god Lim. Possibly, in view of where limm occurs alone, ybmt limm are two juxtaposed titles. She is described as 'Dame of royalty, dame of sovereignty, dame of the skies above, Anat of kpt and Anat who hovers in the skies above'. Other titles for this goddess are $\mathrm{xbly}$, 'Destroyer', xlS 'Ruinous' and (nt spn) 'Anath of Sapon'. Like Athtartu's, her beauty is fabled. She is winged and has horns. W.G. Lambert, Old Testament Mythology in its Ancient Near Eastern Context (VTS, 40); Barnett, R D. 'c Anath, Bac al and Pasargadae', MUSJ 45, 1969, p. 407-422; idem,' The earliest representation of c Anath', ErIsr 14, 1978, p. 28-31; Coogan, M D., a. Canaanite origins and lineage: reflections on the religion of ancient Israel, in: Miller 1987, p.115-126.
}

${ }^{5}$ PM, I, 723; RITA III, 413-14; Cornelius, I., the Many Faces of the Goddess: The Iconography of the SyroPalestinian Goddesses Anat, Astarte, Qedeshet, and Asherah c. 1500-1000 BCE. Fribourg, Switzerland, 2004: Cat $1.1,5$.

${ }^{6}$ Cornelius, I., the Many Faces of the Goddess: The Iconography of the Syro-Palestinian Goddesses Anat, Astarte, Qedeshet, and Asherah c. 1500-1000 BCE. Academic Press Fribourg. Vandenhoeck \& Ruprecht. Gottingen, 2004; Tazawa, Keiko, 2009 Syro-Palestinian deities in New Kingdom Egypt: The hermeneutics of their existence. British Archaeological Reports International Series 1965. Oxford: Archaeopress; Stadelmann, R., 1967 Syrisch-Palastinensische Gottheiten in Ägypten. Probleme der Ägyptologie 5. Leiden: Brill; Albright, W.F. 1939. 'Astarte Plaques and Figurines from Tell Beit Mirsim', Mélanges Syriens offerts à Monsieur René Dussaud, Librairie Orientaliste Paul Geuthner, Paris, p. 107-120

${ }^{7}$ Goddess Anat has a temple at Tanis; it was set up during end of New Kingdom; it had added by Osrkon and other kings; for more information see; Montet, J. P., La nécropole royale de Tanis. Volume 1: Les constructions et le tombeau d'Osorkon II à Tanis. Fouilles de Tanis, ser. ed. Jean Pierre Marie Montet. 1947.

${ }^{8}$ Albright, W.F. 1939. 'Astarte Plaques and Figurines from Tell Beit Mirsim', Mélanges Syriens offerts à Monsieur René Dussaud, Librairie Orientaliste Paul Geuthner, Paris, p. 107-120; Cornelius, I., The Many Faces of the Goddess: The Iconography of the Syro-Palestinian Goddesses Anat, Astarte, Qedeshet, and Asherah c. 1500-1000 BCE. Academic Press Fribourg. Vandenhoeck \& Ruprecht. Gottingen, 2004; Tazawa, Keiko, 2009 Syro-Palestinian deities in New Kingdom Egypt: The hermeneutics of their existence. British Archaeological Reports International Series 1965. Oxford: Archaeopress; Stadelmann, R., 1967 Syrisch59 | P a g e 


\section{Document 2}

Owner of Piece: Dyed statue of Ramses II and Anat. ${ }^{9}$

Location: Habu Temple, Egypt. ${ }^{10}$

Piece no: Egyptian Museum, JE 56366.

Date: New Kingdom, reign of king Ramses II.

Doc. 2

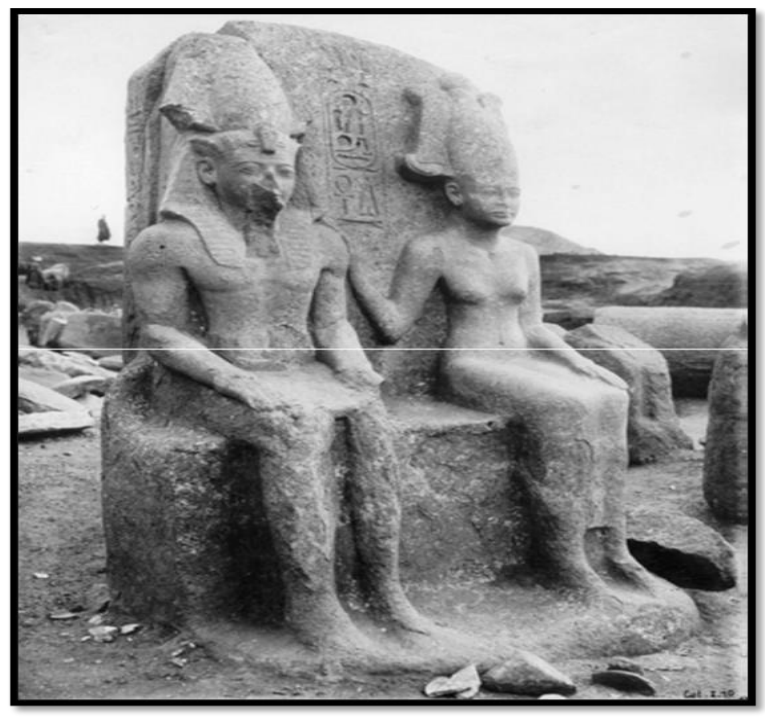

Goddess Anat appears sitting next to Ramses II in a unique dyed gathering them in rare representation. Goddess Anat appears wearing an Atef crown, and her body is hidden under the tight-fitting dress reaching to her ankle. Anat is touching the shoulder of Ramses II gently to indicate the close relation between them. In the second representation of goddess Anat, the artist depicts her in same facial features and wearing crown of Atef. Although there are little representations of goddess Anat with King Ramses II in Egyptian documents, we can conclude that the artist could Egyptianize the goddess Anat. ${ }^{11}$

Palastinensische Gottheiten in Ägypten. Probleme der Ägyptologie 5. Leiden: Brill; Albright, W.F. 1939. 'Astarte Plaques and Figurines from Tell Beit Mirsim', Mélanges Syriens offerts à Monsieur René Dussaud, Librairie Orientaliste Paul Geuthner, Paris, p. 107-120

9 This dyed is extracted from the temple of king Ramses II and goddess Anat at Habu; PM, V, 225; PM, VII, 98; Brooklyn institute of Arts and sciences museum, 1956: 27-28; pls. 51-52; Tazawa, K., 'Syrio- Palestinian Deities in the New Kingdom', in the 9th international congress of Egyptologists, Leuven, Peeters, 2007, p. 1799-1806; PM, II, 59; 159; KRI, II, 233- 256; Cornelius, I, op.cit, 2000:71-73; Leitz, Ch., 2002; Cornelius, I, 2004: Cat 3.8.

${ }^{10}$ Hölscher, U., Medinet Habu 1924-1928. II The Architectural Survey of the Great Temple and Palace of Medinet Habu (season 1927-28). OIC, No. 5. Chicago: University of Chicago Press, 1929; William J. Murnane, United with Eternity - A Concise Guide to the Monuments of Medinet Habu, Oriental Institute, University of Chicago and the American University of Cairo Press, 1980.

${ }^{11}$ Cornelius, I., the Many Faces of the Goddess: The Iconography of the Syro-Palestinian Goddesses Anat, Astarte, Qedeshet, and Asherah c. 1500-1000 BCE. Academic Press Fribourg. Vandenhoeck \& Ruprecht. Gottingen, 2004; Tazawa, Keiko, 2009 Syro-Palestinian deities in New Kingdom Egypt: The hermeneutics of their existence. British Archaeological Reports International Series 1965; Budin, Stephanie L. (2004). "A Reconsideration of the Aphrodite-Ashtart Syncretism". Numen. 51 (2): 95-145; Tazawa, K., 2009 SyroPalestinian deities in New Kingdom Egypt: The hermeneutics of their existence. British Archaeological Reports International Series 1965. Oxford: Archaeopress; Stadelmann, R., 1967 Syrisch-Palastinensische Gottheiten in Ägypten. Probleme der Ägyptologie 5. Leiden: Brill; Albright, W.F. 1939. 'Astarte Plaques and Figurines from Tell Beit Mirsim', Mélanges Syriens offerts à Monsieur René Dussaud, Librairie Orientaliste Paul Geuthner, Paris, p. 107-120; Dijkstra, M., 'The Myth of Astarte the Huntress, (KTU 1.92, New Fragments)'. UF 26, 1994, p. 113-126; Roth, A.M., 'Father Earth, Mother Sky: Ancient Egyptian Beliefs about Conception and Fertility.' 60 | P a g e 


\section{Goddess Ashtart ${ }^{12}$}

\section{Document 3}

Owner of Piece: Stela of goddess Ashtart with

King Ramses II.

Location: Qantir, Lower Egypt. ${ }^{13}$

Piece no: Louvre Museum, E.26017.

Date: New Kingdom, 19th Dynasty, reign of king Ramses II. ${ }^{14}$

Doc 3: It is rounded topped stela missing the lower part showing three figures. In the lunette is couchant Seth animal looking to the right. There are four lines of texts around it. Underneath is Ramses

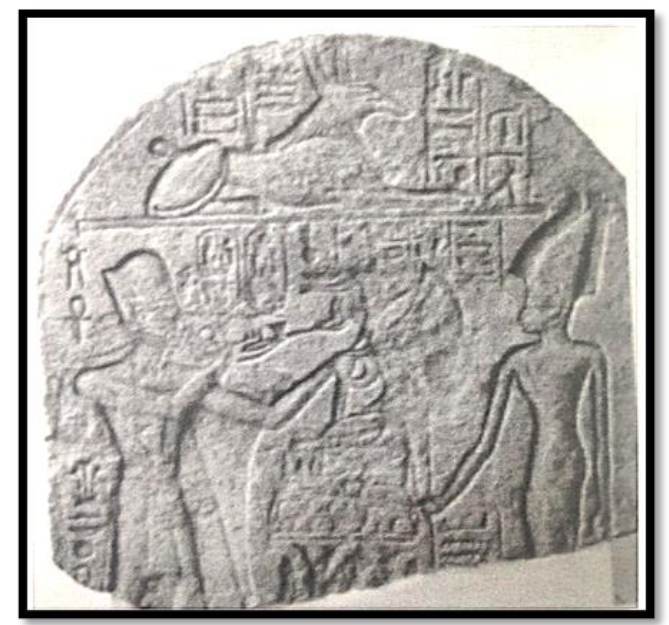
II who is identified by cartouche in front of him offering some Lotus flower in his left hand and incense in his right hand to goddess. She is shown wearing an Atef-crown with two feathers. Between them there is a heaped offering table. The main scene shoes king Ramses II while presenting a lotus and burning incense before goddess Astrat. Goddess Astrat is standing holding a scepter in her right hand and Ank sign in her left hand. ${ }^{15}$

In Rautman (ed.), Reading the Body: Representations and Remains in the Archaeological Record, University of Pennsylvania Press. Philadelphia, 2000, p. 187-201.

${ }^{12}$ Astarte was a Near Eastern war goddess who was introduced into Egypt during the Second Intermediate Period. In Egyptian myths she was the daughter of Ra or Ptah and a consort of Seth. She was worshipped by the Philistines as Ashtoreth and the Canaanites as Ashera. A warrior goddess of Canaan and Syria who is a Western Semitic counterpart of the Akkadian Ishtar worshipped in Mesopotamia. When the Peleset (Philistines) killed Saul and his three sons on Mount Gilboa, they deposited the enemy armour as spoils in the temple of 'Ashtoreth' (Astarte). Like Aat she is the daughter of Ra and the wife of the god Seth but also has a relationship with the god of the sea. ${ }^{12}$ From the woefully fragmentary papyrus giving the legend of Astarte and the sea the following information can be gleaned: the sea-god Yamm demands tribute from the gods which involves the goddess of harvest Renenutet. Her place is then taken by Astarte called here 'daughter of PTAH'. The story is lost from this point on but one assumes this liaison results in the goddess tempering the arrogance of Yamm. She is an astral goddess (although possibly androgynous in origin) worshipped in Mesopotamia as 'lady of battle' and as an embodiment of sexuality and fertility. She is the Eastern Semitic counterpart of Astrat (who figures far more prominently in Egyptian theology) and the Akkadian equivalent of the Sumerian goddess Inanna; Stadelmann, R., 1967 SyrischPalastinensische Gottheiten in Ägypten. Probleme der Ägyptologie 5. Leiden: Brill; Albright, W.F. 1939. 'Astarte Plaques and Figurines from Tell Beit Mirsim', Mélanges Syriens offerts à Monsieur René Dussaud, Librairie Orientaliste Paul Geuthner, Paris, p. 107-120; Albright, W.F. 1939. 'Astarte Plaques and Figurines from Tell Beit Mirsim', Mélanges Syriens offerts à Monsieur René Dussaud, Librairie Orientaliste Paul Geuthner, Paris, p. 107-120; Cornelius, I., The Many Faces of the Goddess: The Iconography of the Syro-Palestinian Goddesses Anat, Astarte, Qedeshet, and Asherah c. 1500-1000 BCE. Academic Press Fribourg. Vandenhoeck \& Ruprecht. Gottingen, 2004,

${ }^{13}$ Tazawa, K., 2009 Syro-Palestinian deities in New Kingdom Egypt: The hermeneutics of their existence. British Archaeological Reports International Series 1965. Oxford: Archaeopress; Stadelmann, R., 1967 SyrischPalastinensische Gottheiten in Ägypten. Probleme der Ägyptologie 5. Leiden: Brill; Albright, W.F. 1939. 'Astarte Plaques and Figurines from Tell Beit Mirsim', Mélanges Syriens offerts à Monsieur René Dussaud, Librairie Orientaliste Paul Geuthner, Paris, p. 107-120; Dijkstra, M., 'The Myth of Astarte the Huntress, (KTU 1.92, New Fragments)'. UF 26, 1994, p. 113-126; Roth, A.M., 'Father Earth, Mother Sky: Ancient Egyptian Beliefs about Conception and Fertility.' In Rautman (ed.), Reading the Body: Representations and Remains in the Archaeological Record, University of Pennsylvania Press. Philadelphia, 2000, p. 187-201

${ }^{14}$ Roth, A.M., 'Father Earth, Mother Sky: Ancient Egyptian Beliefs about Conception and Fertility.' In Rautman (ed.), Reading the Body: Representations and Remains in the Archaeological Record, University of Pennsylvania Press. Philadelphia, 2000, p. 187-201.

${ }^{15}$ K. van der Toorn, Bob Becking, Pieter Willem van der Horst, Dictionary of Deities and Demons in the Bible, p. 109-10; Budin, Stephanie L. (2004). "A Reconsideration of the Aphrodite-Ashtart Syncretism". Numen. 51 (2): 95-145; Tazawa, K., 2009 Syro-Palestinian deities in New Kingdom Egypt: The hermeneutics of their existence. British Archaeological Reports International Series 1965. Oxford: Archaeopress; Stadelmann, R., 1967 Syrisch-Palastinensische Gottheiten in Ägypten. Probleme der Ägyptologie

$61 \mid \mathrm{P}$ a g e 


\section{Document 4}

Owner of Piece: fragment stela of goddess Astrat.

Location: Saft el Henna, ${ }^{16}$ Lower Egypt.

Piece no: University College Museum, London, and UC 14399.

Date: New Kingdom, 19th Dynasty, reign of Ramses II

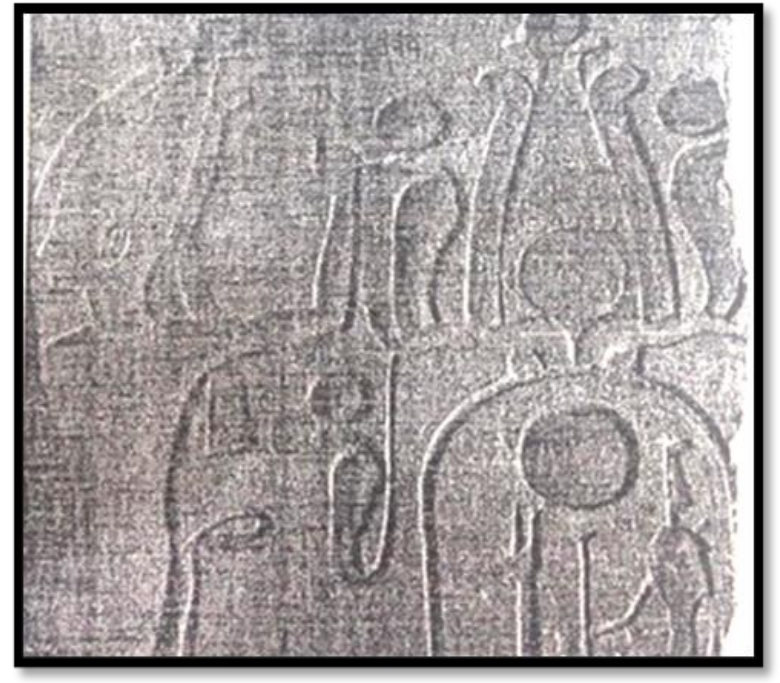

\section{Doc 4}

Doc 4: It is a fragment stela which shows Astrat standing in front of Ramses II. She is a female figure in standing pose as warrior, wearing an Atef-crown with hanging scarf. Her left hand holds a lance. Behind Astrat we can see the cartouche of Ramses II fastened with Atef crown and two alarmed serpents

5. Leiden: Brill; Albright, W.F. 1939. 'Astarte Plaques and Figurines from Tell Beit Mirsim', Mélanges Syriens offerts à Monsieur René Dussaud, Librairie Orientaliste Paul Geuthner, Paris, p. 107-120; Dijkstra, M., 'The Myth of Astarte the Huntress, (KTU 1.92, New Fragments)'. UF 26, 1994, p. 113-126; Roth, A.M., 'Father Earth, Mother Sky: Ancient Egyptian Beliefs about Conception and Fertility.' In Rautman (ed.), Reading the Body: Representations and Remains in the Archaeological Record, University of Pennsylvania Press. Philadelphia, 2000, p. 187-201.

${ }^{16}$ Beck, P., 'A New Type of Female Figurine.' In M. Kelly-Buccellati, P. Matthias, and M. Van Loon (eds.) Insight through Images: Studies in Honor of Edith Porada, 1986, p. 29-34 and Plate 16; Dijkstra, M., 'The Myth of Astarte the Huntress, (KTU 1.92, New Fragments)'. UF 26, 1994, p. 113-126 


\section{Document 5}

Owner of Piece: fragment stela of goddess Ashtart.

Location: Qantir, ${ }^{17}$ Lower Egypt.

Piece no: University College Museum, London, UC 143100.

Date: New Kingdom, 19th Dynasty, reign of Ramses II

\section{Doc. 5}

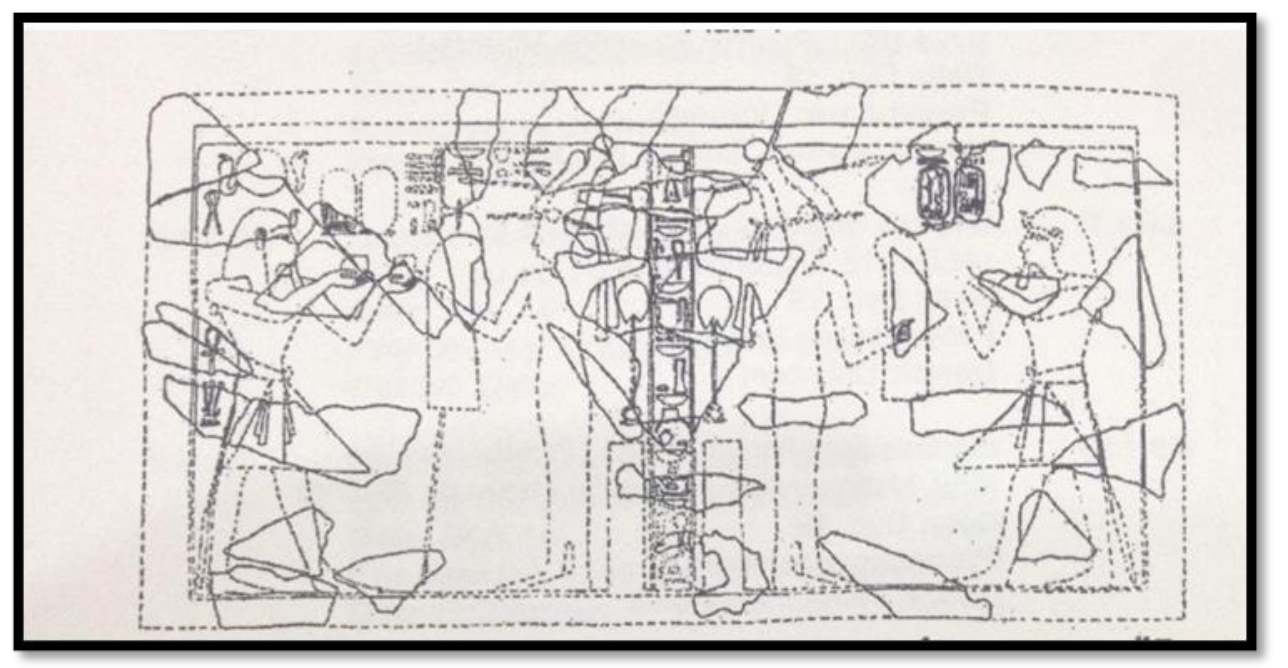

It is a fragment stela showing Astrat standing in front of Ramses II. She is shown as a female figure in a standing pose as warrior. She is wearing an Atef-crown with hanging scarf. Her left hand holds a lance. Behind Astrat we can see the cartouche of Ramses II fastened with Atef crown and two alarmed serpents. The double scene shows king Ramses II before goddess Astrat while presenting the $n w$ jars. . ${ }^{18}$

${ }^{17}$ Qantir (Khatana-Qantir) is a village in Egypt. Qantir is believed to mark what was probably the ancient site of the 19th dynasty Pharaoh Ramesses II's capital, Pi-Ramesse or Per-Ramesses ("House or Domain of Ramesses"). This city is situated around 9 kilometers (5.6 mi) north of Faqous in the Sharqiyah province of the eastern Nile Delta, about 60 miles north-east of Cairo The ancient site of Avaris is located around 2 kilometers $(1.2 \mathrm{mi})$ south of Qantir. This was the older city in this area. Later on, Avaris was absorbed by Pi-Ramesses; for more information see; Beck, P., 'A New Type of Female Figurine.' In M. Kelly-Buccellati, P. Matthias, and M. Van Loon (eds.) Insight through Images: Studies in Honor of Edith Porada, 1986, p. 29-34 and Plate 16; Dijkstra, M., 'The Myth of Astarte the Huntress, (KTU 1.92, New Fragments)'. UF 26, 1994, p. 113-126; K. Kris Hirst - A Glass Making Workshop for the Pharaoh Ramses II - History of Glass Making in Egypt's New Kingdom - Archaeology - About.com. Retrieved 20 August 2011.

${ }^{18}$ Stadelmann, R., 1967 Syrisch-Palastinensische Gottheiten in Ägypten. Probleme der Ägyptologie 5. Leiden: Brill; Albright, W.F. 1939. 'Astarte Plaques and Figurines from Tell Beit Mirsim', Mélanges Syriens offerts à Monsieur René Dussaud, Librairie Orientaliste Paul Geuthner, Paris, p. 107-120; Albright, W.F. 1939. 'Astarte Plaques and Figurines from Tell Beit Mirsim', Mélanges Syriens offerts à Monsieur René Dussaud, Librairie Orientaliste Paul Geuthner, Paris, p. 107-120; Cornelius, I., The Many Faces of the Goddess: The Iconography of the Syro-Palestinian Goddesses Anat, Astarte, Qedeshet, and Asherah c. 1500-1000 BCE. Academic Press Fribourg. Vandenhoeck \& Ruprecht. Gottingen, 2004; Tazawa, Keiko, 2009 Syro-Palestinian deities in New Kingdom Egypt: The hermeneutics of their existence. British Archaeological Reports International Series 1965. Oxford: Archaeopress. Stadelmann, R., 1967 Syrisch-Palastinensische Gottheiten in Ägypten. Probleme der Ägyptologie 5. Leiden: Brill; Albright, W.F. 1939. 'Astarte Plaques and Figurines from Tell Beit Mirsim', Mélanges Syriens offerts à Monsieur René Dussaud, Librairie Orientaliste Paul Geuthner, Paris, p. 107-120

63 | P a g e 


\section{Document 6}

Owner of Piece: Relief of Ramses II and goddess Ashtart.

Location: Tanis, ${ }^{19}$ Lower Egypt.

Piece no: Louvre Museum, A 26017. ${ }^{20}$

Date: New Kingdom, 19th Dynasty, reign of Ramses II.

\section{Doc. 6}

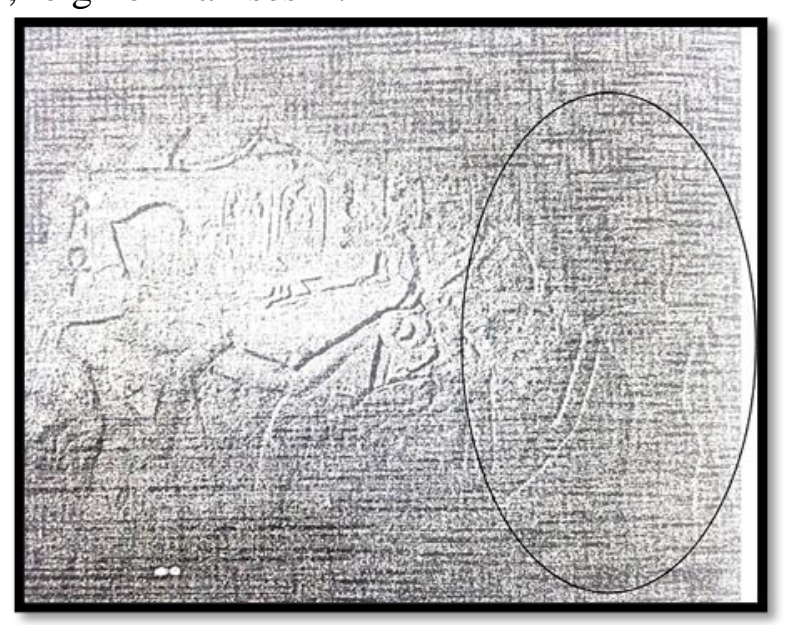

The scene shows king Ramses II burning incense before goddess Astrat. Ramses II gives offerings to Astrat and there is a table heaped with offerings. Astrat is represented as a full female in standing pose and is wearing an Atef-crown. It is worth noting that Astrat is depicted wearing a tight-fitting garment reaching to her ankle. The king appears in standing pose and is wearing a blue crown. His whole body is hidden under bag-tunic with short sleeves. Nb tAwy wsr mAat ra stp $n$ ra sA ra mry imn ra msw mryt $n$ asrt di anx $D t$ The lord of two lands (Ramses II) son of god re (birth name of Ramses II), beloved of Astrat, may give life forever. ${ }^{21}$

19 Tanis is a city in the north-eastern Nile Delta of Egypt. It is located on the Tanitic branch of the Nile which has long since silted up, Tanis is unattested before the 19th Dynasty of Egypt, when it was the capital of the 14th Nome of Lower Egypt. A temple inscription datable to the reign of Ramesses II mentions a "Field of Tanis", while the city in se is securely attested in two 20th Dynasty documents: the Onomasticon of Amenope and the Story of Wenamun, as the home place of the pharaoh-to-be Smendes; Loth, Marc, 2014. "Tanis 'Thebes of the North' “. In "Egyptian Antiquities from the Eastern Nile Delta", Museums in the Nile Delta, Vol. 2, ser. ed. by Mohamed I. Bakr, Helmut Brandl, and Faye Kalloniatis. Cairo/Berlin: Opaion; Montet, Jean Pierre Marie. 1947. La nécropole royale de Tanis. Volume 1: Les constructions et le tombeau d'Osorkon II à Tanis. Fouilles de Tanis, ser. ed. Jean Pierre Marie Montet. Paris; idem, 1951. La nécropole royale de Tanis. Volume 2: Les constructions et le tombeau de Psousennès à Tanis. Fouilles de Tanis, ser. ed. Jean Pierre Marie Montet. Paris; idem, 1960. La nécropole royale de Tanis. Volume 3: Les constructions et le tombeau de Chechanq III à Tanis. Fouilles de Tanis, ser. ed. Jean Pierre Marie Montet. Paris.

${ }^{20}$ Easton M.A., D.D., illustrated Bible Dictionary; 1897, topic: Ashtoreth; Skipwith, G. H., ' Ashtoreth, the Goddess of the Zidonians' Center for Advanced Judaic Studies, University of Pennsylvania, The Jewish Quarterly Review, Vol. 18, No. 4, 1906, p. 715-738.

21 Badawy, A., A History of Egyptian Architecture. The First Intermediate Period, the Middle Kingdom, and the Second Intermediate Period, Berkeley, 1966, p. 75; Leitz, Ch, 1999 Magical and medical papyri of the New Kingdom. Hieratic Papyri in the British Museum 7. London: British Museum; Hart, G., Egyptian Gods and Goddesses; M.G. Easton M.A., D.D., Illustrated Bible Dictionary; 1897: Ashtoreth. Skipwith, G. H., ' Ashtoreth, the Goddess of the Zidonians' Center for Advanced Judaic Studies, University of Pennsylvania, The Jewish Quarterly Review, Vol. 18, No. 4 (Jul., 1906), pp. 715-738; A. L. Perlman. Asherah and Astarte in the Old Testament and in Ugaritic Literature. Berkeley: 1978. J. B. Pritchard. Palestinian Figurines in Relation to Certain Goddesses Known through Literature. New Haven: 1943. Primary Sources: H\&S; Astarte and the Sea; P. Leiden I 34364 | P a g e 


\section{God Baal 22}

\section{Document 7}

Owner of Piece: The 400-year stela of god Baal.

Location: Tanis, Egypt. ${ }^{23}$

Piece no: Egyptian Museum, Cairo, and CG. 4221, J.E 57682 24

Date: New Kingdom, 19th Dynasty, reign of king Ramses II.

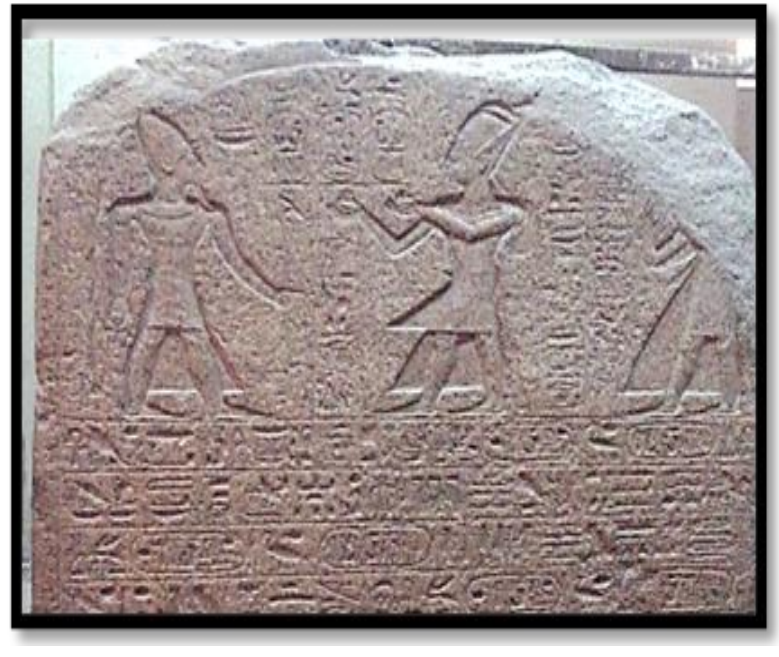

345.4; HMP; Beck, P. 1986. 'A New Type of Female Figurine.' In M. Kelly-Buccellati, P. Matthiae, and M. Van Loon (eds.) Insight Through Images: Studies in Honor of Edith Porada. Undena Publications. Malibu, 29-34.

${ }^{22}$ Ba'al (bet-ayin-lamedh) is a Semitic word signifying 'The Lord, master, owner (male), keeper, and husband', ${ }^{22}$ which became the usual designation of the great weather-god of the Western Semites. Cognates include

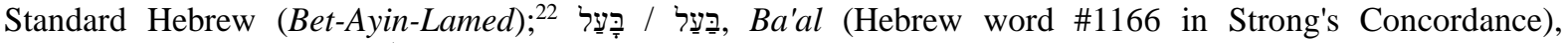
Akkadian Bēl and Arabic بعل. In Hebrew, the word Ba'al means 'husband' or 'owner' and is related to a verb meaning to take possession of, for a man, to consummate a marriage. ${ }^{22}$ The word 'Ba'al' is also used in many Hebrew phrases, denoting both concrete ownership as well as possession of different qualities in one's personality. ${ }^{22}$ Baal is a prominent god of the sky and storms whose cult spread from Ugarit in Syria into Egypt, where he possessed priesthood by Dynasty XVIII. Aliyan Baal, son of a less well-attested god Dagan, dwelt on Mount Sapan (hence Baal-Zaphon) in north Syria but also became associated as a local deity of other sites such as Baal-Hazor in Palestine, and Baal-Sidon and Baal of Tyre (Melkart) in Lebanon. Although the name Baal can mean 'lord' or 'owner' it was being used as a proper name for a specific god by the sixteenth century BC. Baal, Egyptian Mentioned first by Amenhotep II the god found few adherents among the native kings before the 19th dynasty, having been a major deity of the Hyksos enemies, but he had entered the pantheon of Peru-nefer near Memphis by the reign of Thutmose III and his cult was well established under the 18th dynasty. ${ }^{22}$ His importance grew under Ramses II when he rose to prominence as Seth-Baal, ${ }^{22}$ but his cult declined at the beginning of the first millennium BCE when Seth fell from favor and was more and more considered to be wholly evil. ${ }^{22}$ Baal's original roles of storm and fertility god were abandoned in favor of his new function of defender of creation, battling serpents and lions, taming the sea, ${ }^{[6]}$ and supporting the military endeavors of the pharaohs against their foreign enemies, who liked to compare themselves to the god and the terror he inspired, as did Seti I at Karnak: great with fear like Baal over the foreign countries, Albright, W. F., 1932. The North Canaanite Epic of Aleyan Bad and Mot. Jorma1 of the Palestine Oriental Society 12, p. 185-208; Budde, D., Lexikon der Ägyptischen Götter und Golterhezeichnungen, Volume 1, Peeters Publishers, 2003; Günter B., Heinz J. Thissen, Einführung in die Altägyptischen Literaturgeschichte, Volume 2, LIT Verlag BerlinHamburg-Münster, 2003.

${ }^{23}$ Battenfield, J.R., 1988. Yahweh's Refutation of the Bad Myth Through the Actions of Elijah. In Israel's Apostasy and Restoration: Essays in Honor of Roland K. Harrison., Edited by A. Gileadi., p. 19-37; Cornelius, I., The Iconography of the Canaanite Gods Reshef and Ba'al. Late Bronze and Iron Age I Periods (c 1500 - 1000 BCE), Fribourg (Switzerland), University Press /Gottingen, Vandenhoeck \& Ruprecht 1994; Ithamar Gruenwald, Ilai Alon, Itamar Singer, Concepts of the Other in Near Eastern Religions, Brill, 1994; Otto Kaiser, Die mythische Bedeutung des Meeres in Ägypten, Ugarit und Israel, Alfred Töpelmann, Berlin 1962; The

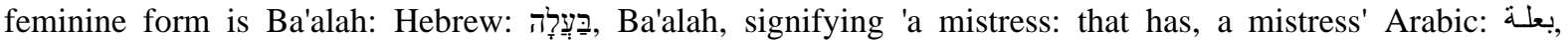
balalah, a rare word for "wife"; Te Velde, H., Seth, God of Confusion: a study of his role in Egyptian mythology and religion, Brill Archive, 1977; Zeitschrift für Ethnologie, 3, 1871, p.139

24 Tazawa, Keiko, Syro-Palestinian deities in New Kingdom Egypt: The hermeneutics of their existence, Op.cit; Helck, Wolfgang, 1966 Zum Auftreten fremder Götter in Ägypten. Oriens Antiques, P. 22; Schneider, Thomas, Foreign Egypt: Egyptology and the concept of cultural appropriation, Ägypten und Levante 2003, p.140-151

65 | P a g e 


\section{Doc. 7}

This stela, which was discovered by August Mariette, is designed in round top with 3 figures on the surface. The first character is a male figure of god Baal who is characterized as Egyptian god Seth. He is depicted with conical crown which looks like the Egyptian white crown with disk and horns. The Egyptian artist was skillful enough in representing Baal with Egyptian features and elements but with some new ethnicity. Baal is wearing a foreign crown and there is a single streamer running from the tip of the crown to the ankles, ending in a flower. Baal is represented with an Egyptian beard and is dressed in a decorated knee-length kilt which is fastened to the body by two bands crossing over the chest. There is a broad necklace around his neck and bangles on the wrists. King Ramses II is represented on right hand side when giving the offering to god Baal. He is depicted with all Egyptian royal features. The third figure may in identical guard with his hands in a gesture of praise.

\section{Document 8 \\ Owner of Piece: Stela of Baal and Ramses II \\ Location: Egypt. \\ Piece no: Egyptian Museum, Cairo, and JE. 88879 \\ Date: New Kingdom, 19th Dynasty, New Kingdom.}

\section{Doc. 8}

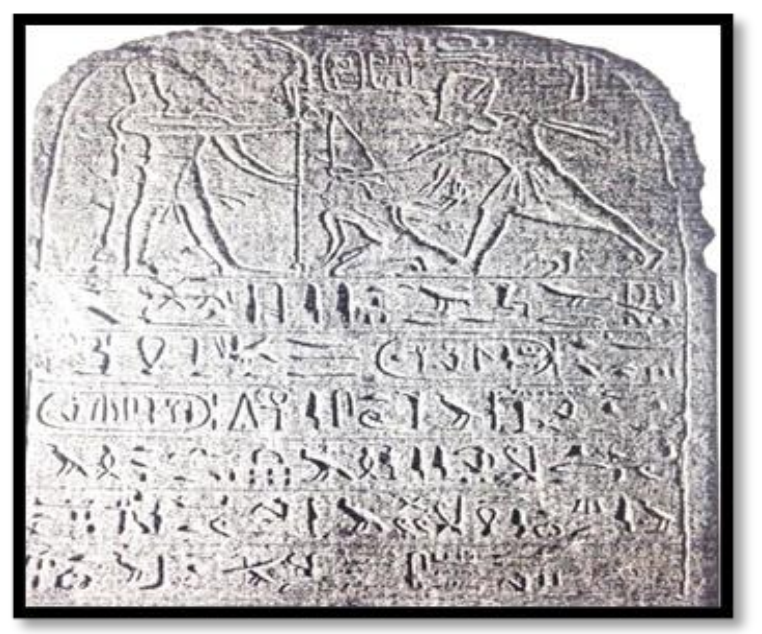

This is a stela which represents god Baal in standing pose while helping king Ramses II to smite enemy. He gives king Ramses a kbsh sword with his right hand upraised with a grasp or a spear for killing and the other hand appear holding a person from his locks of hair in kneeling pose. Baal may appear with the white crown and long streamer. He also appears wearing the Asiatic kilt with tassels. ${ }^{25}$

\footnotetext{
25 Török, L., "The Costume of the Ruler in Meroe: Remarks in its Origins and Significances", in: Archéologie Du Nil Moyen 4, 1990, p.151-201; Relief of King Shabitko on the east side of the façade of the Osiris-Hekhdjet chapel in the great temple of Amun at Karnak; for more details see; Schwaller de Lubicz, R.A., Les temples de Karnak, II, Paris, 1982, pl.233; see also, Török, L., op.cit, 1990, p.155, fig 6; Relief of King Taharqa in a procession from Kawa temple, T temple, hypostyle hall, south wall; for more details see: Macadam, L., The Temples of Kawa, II, London, 1955, Pl.XV a, b; Griffith, F.L.I., Oxford Excavation in Nubia, LAAA 9, Pl. XXVII; Török, L., op.cit, 1990, p. 151-202, fig 4, 5. Relief of king Ramses III and his son before Duamutef, Valley of the Queen, N.55, Vestibule; see: Hassanein, F and Nelson, M., La tombe du prince Amon Her Khepeshf, Le Caire, 1976, Pl.XVII; Relief of royal scribe Pa Ra m nb from his funerary papyrus; see Mathieu, B., "Un Nouveau Fragment de Papyrus de Paremnb", in: $\boldsymbol{R} \boldsymbol{d} \boldsymbol{E}$ 37, 1986, p. 155-159, fig p.156.; Török (op.cit, 1990, p.151-202) tried to prove his hypothesis through reliefs of priests of Amun at Karnak and priests of Amun at Kawa
}

66 | P a g e 


\section{Document 9}

Owner of Piece: Baal with king Ramses II. ${ }^{26}$

Location: Medinet Habu, Egypt.

Piece no: in Situation

Date: New Kingdom, 19th Dynasty

\section{Doc. 9}

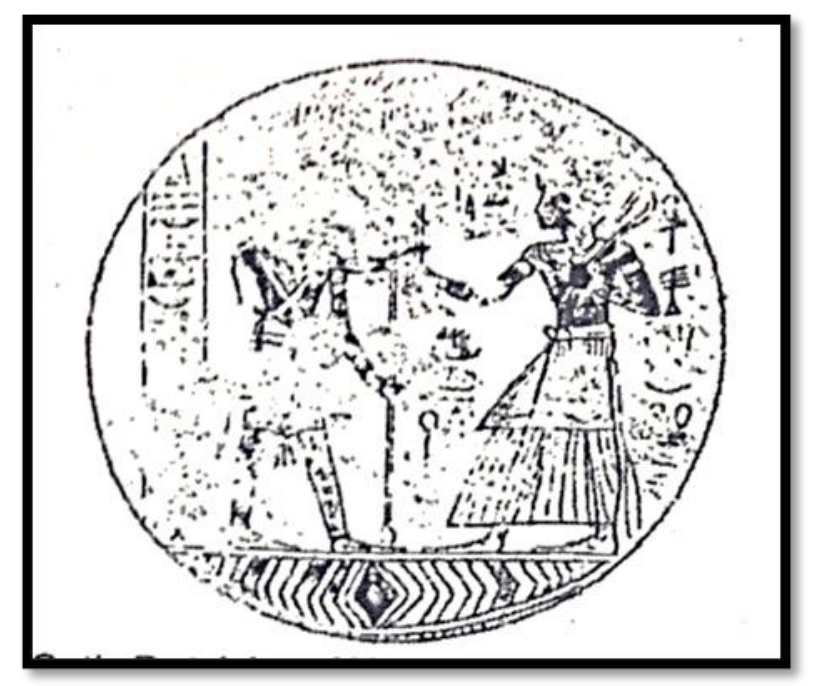

This stela represents god Baal in standing pose while helping king Ramses II to smite enemy. He gives king Ramses a kbsh sword with his right hand upraised with a grasp or a spear for killing and the other hand appear holding a person from his locks of hair in kneeling pose. Baal may appear with the white crown and long streamer. He also appears wearing the Asiatic kilt with tassels. In this representation, king Ramses II appears wearing a composite dress with a tall skirt with starched apron in pleated lines. The skirt is knotted by a wide strap fixing on the right shoulder. This dress is Ramesside style fashion. God Baal is standing in front of the king, and wearing a Syrian fashion style kilt with distinguish tassels. ${ }^{27}$

${ }^{26}$ Thirion, M., 1986 Notes d'Onomastique: Contribution à Une revision du Ranke PN', Revue d'Egyptologie 37, pp. 125-131

27 The tassel is fashion style appears in different civilization; for example, during $25^{\text {th }}$ Dynasty the Kushite kings appears with Egyptian clothes with tassels ends. In Syrian culture there are existence for this tassel on the costumes; for more information see; during the Twenty-Sixth Dynasty", in: JEA 88, 2002, p.179-186, see also; Lohwasser, A., "Queenship in Kush: Status, Role and Ideology of Royal Women", in: JARCE 38, 2001, p.6176; Shrine of king Taharqa in the Ashmolean Museum, Oxford; see: Macadam, L., The Temples of Kawa, I \& II, London, 1949 \& 1955. The reconstruction of the shrine was described by E.T. Leeds in The Museums Journal 41 (1942), 228-30; Török, L., "The Costume of the Ruler in Meroe: Remarks in its Origins and Significances", in: Archéologie Du Nil Moyen 4, 1990, p.151-201; Relief of King Shabitko on the east side of the façade of the Osiris-Hekhdjet chapel in the great temple of Amun at Karnak; for more details see; Schwaller de Lubicz, R.A., Les temples de Karnak, II, Paris, 1982, pl.233; see also, Török, L., op.cit, 1990, p.155, fig 6; Relief of King Taharqa in a procession from Kawa temple, T temple, hypostyle hall, south wall; for more details see: Macadam, L., The Temples of Kawa, II, London, 1955, Pl.XV a, b; Griffith, F.L.I., Oxford Excavation in Nubia, LAAA 9, Pl. XXVII; Török, L., op.cit, 1990, p. 151-202, fig 4, 5. Relief of king Ramses III and his son before Duamutef, Valley of the Queen, N.55, Vestibule; see: Hassanein, F and Nelson, M., La tombe du prince Amon Her Khepeshf, Le Caire, 1976, Pl.XVII; Relief of royal scribe Pa Ra $m \mathrm{nb}$ from his funerary papyrus; see Mathieu, B., "Un Nouveau Fragment de Papyrus de Paremnb", in: RdE 37, 1986, p. 155-159, fig p.156.; Török (op.cit, 1990, p.151-202) tried to prove his hypothesis through reliefs of priests of Amun at Karnak and priests of Amun at Kawa.

67 | P a g e 


\section{Document 10}

Owner of Piece: Baal with king Ramses II.

Location: Tanis, Egypt.

Piece no: in Situation

Date: New Kingdom, 19th Dynasty

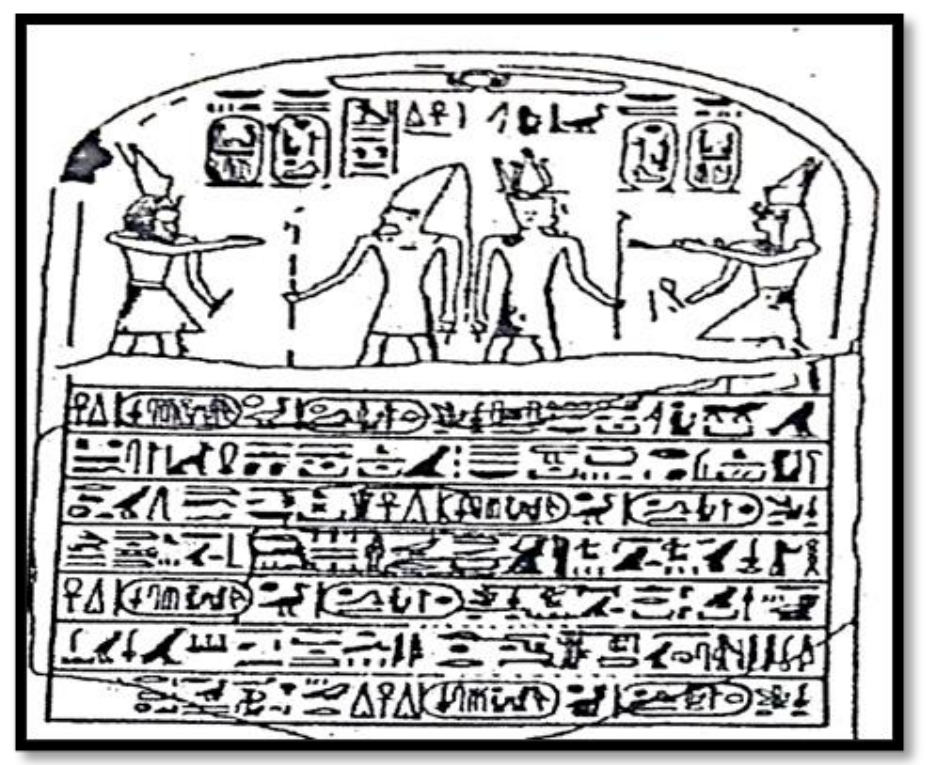

\section{Doc. 10}

God Baal appears standing in front of king Ramses II who gives him offerings. Baal appears as an Egyptian god with white crown and short bag tunic reaching to his knees. He appears wearing the false beard with a broad collar. It is an unusual stela which represents king Ramses II facing god Baal in different costumes and regalia. Once upon time with Egyptian white crown hanging from its back rope with short tight tunic. On the other representation, Baal appears wearing the composite crown. ${ }^{28}$

28 Smith, William Robertson (1878), "Baal" , in Baynes, T. S. (ed.), Encyclopædia Britannica, 3 (9th ed.), New York: Charles Scribner's Sons, pp. 175-176; Schniedewind, William; Hunt, Joel (2007), A Primer on Ugaritic: Language, Culture, and Literature, Cambridge: Cambridge University Press; Halpern, Baruch (2009), Adams, M.J. (ed.), From Gods to God: The Dynamics of Iron Age Cosmologies, Tübingen: Mohr Siebeck (Ser. Forschungen zum Alten Testament, No. 63; Herrmann, Wolfgang (1999a), "Baal", in Toorn, Karel van der; Becking, Bob; Horst, Pieter Willem van der (eds.), Dictionary of Deities and Demons in the Bible, 2nd ed., Grand Rapids: Wm. B. Eerdmans Publishing, p. 132-139 


\section{Document 11}

Owner of Piece: Baal with king Ramses II

Location: Saft el Hanna, Egypt.

Piece no: in Situation

Date: New Kingdom, 19th Dynasty, New Kingdom.

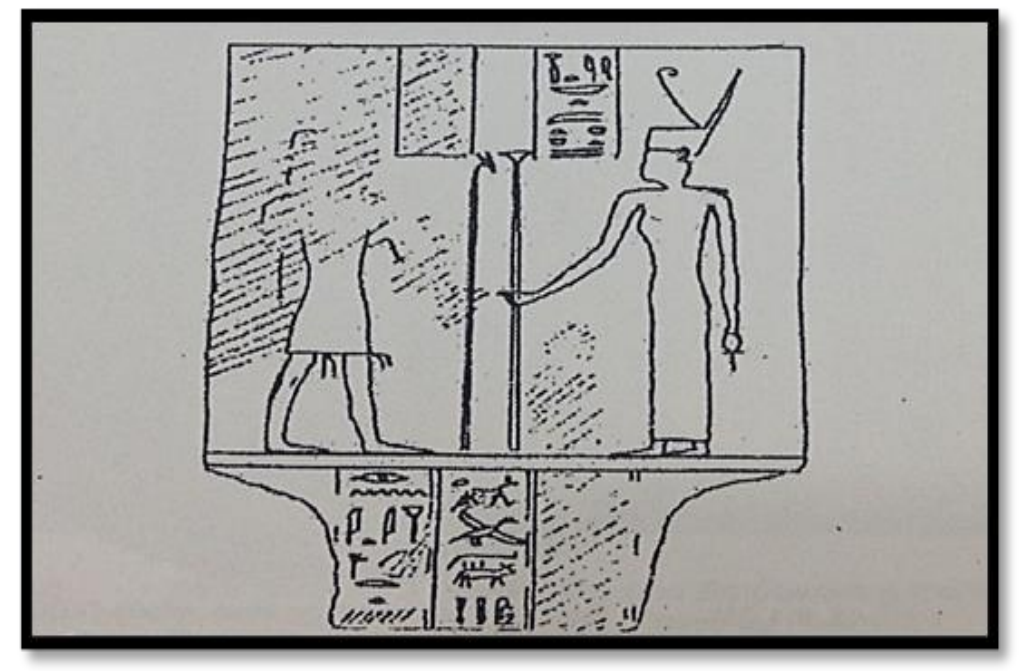

\section{Doc 11}

This is a rare representation of god Baal standing in front of Neith, the Egyptian goddess of war in ancient Egyptian beliefs. The relief of Baal is demolished but we can trace that Baal appears wearing the bag-tunic with Asian frontal tassels and holding in his right hand the was scepter. The Egyptian goddess Neith appear wearing a tight long dress with red crown on her head and holding the papyrus staff with her right hand and Ank sign with the other hand. The scarcity and non-repetition of the scene is represented by the appearance of Neith, the Egyptian goddess of war, before god Baal, ${ }^{29}$ who is considered the foreign god of evil or war. The artist tried to emphasize this by showing the Egyptian goddess and her equivalent in the Asian culture. ${ }^{30}$

${ }^{29}$ Ayali-Darshan, Noga, "Baal, Son of Dagan: In Search of Baal's Double Paternity", Journal of the American Oriental Society, Vol. 133, No. 4, 2013, p. 651-657; Halpern, Baruch (2009), Adams, M.J. (ed.), From Gods to God: The Dynamics of Iron Age Cosmologies, Tübingen: Mohr Siebeck (Ser. Forschungen zum Alten Testament, No. 63; Herrmann, Wolfgang (1999a), "Baal", in Toorn, Karel van der; Becking, Bob; Horst, Pieter Willem van der (eds.), Dictionary of Deities and Demons in the Bible, 2nd ed., Grand Rapids: Wm. B. Eerdmans Publishing, p. 132-139

${ }^{30}$ Lesko, Barbara S., The Great Goddesses of Egypt. University of Oklahoma Press. 1999, p. 60-63; "The Gods of the Egyptians: Vol 2", E. A. Wallis Budge, p. 220. 


\section{Discussion and Results}

King Ramses II is considered one of the most Egyptian kings who appeared in various representations with foreign gods. Artists tried hard to depict these gods and goddesses with an Egyptian appearance that is in line with the Egyptian king while preserving the foreign tendency of each god. These deities were worshiped under their foreign name while being depicted in Egyptian fashion. Their principal function was providing protection. It is the very nature of Egyptian polytheism that allowed for foreign divinities to acquire the same status as the indigenous gods. King Ramses II may be the only king in the Egyptian civilization who appear with numerous of foreign deities. The majority of these gods were Asiatic or Syriopalastine gods. The researcher also concluded that the majority of his representations were stela not statues except the representation with goddess Anat.

King Ramses II assured his Egyptian authority on the new empire in Syria by depicting himself with gods and goddesses of this foreign civilization. The researcher introduces her own view concerning the spreading of these foreign deities in Egypt, especially during the New Kingdom period. For example, there was a strong tie between Egypt and Syro-Palestine. Egyptian troops serving in the Levant took their own deities along and returned to Egypt with knowledge of the deities of the countries where they served. Foreign merchants and sailors were also instrumental in introducing deities previously unknown in Egypt.

Chart 1 and 2 indicate the costumes of goddess Anat in her representations with king Ramses II. Chart 1 displays the crowns which Anat appears wearing. We can notice that the osiarian Atef crown occupied high pose among other crowns. It takes the Egyptian features without any Syrian additions.

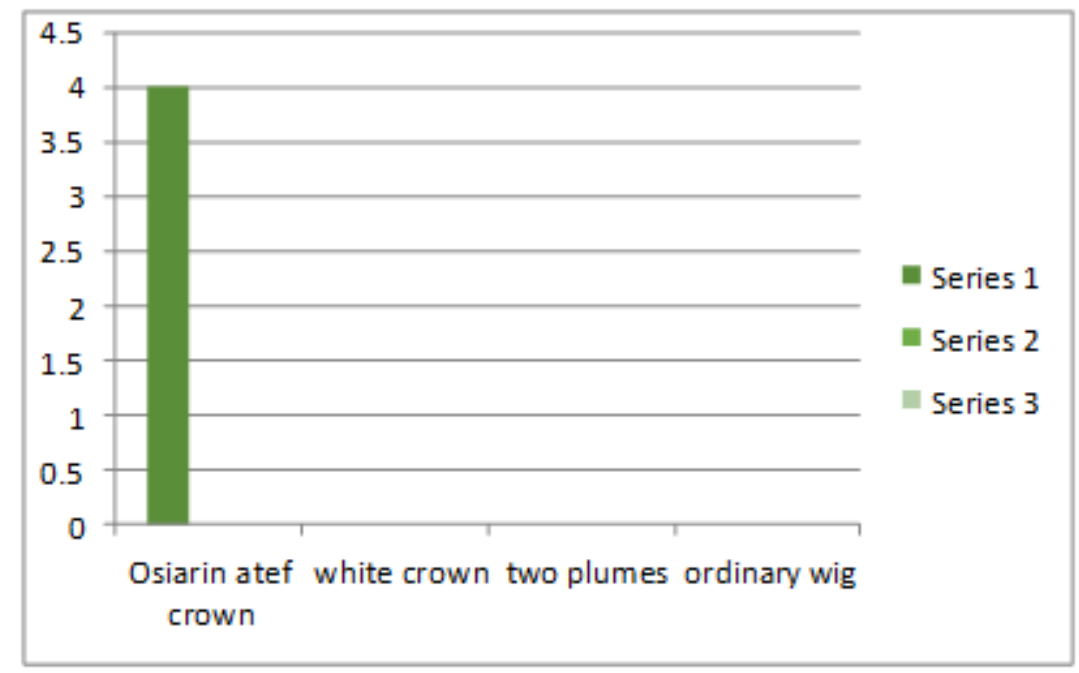

Chart.1. The crowns of goddess Anat 


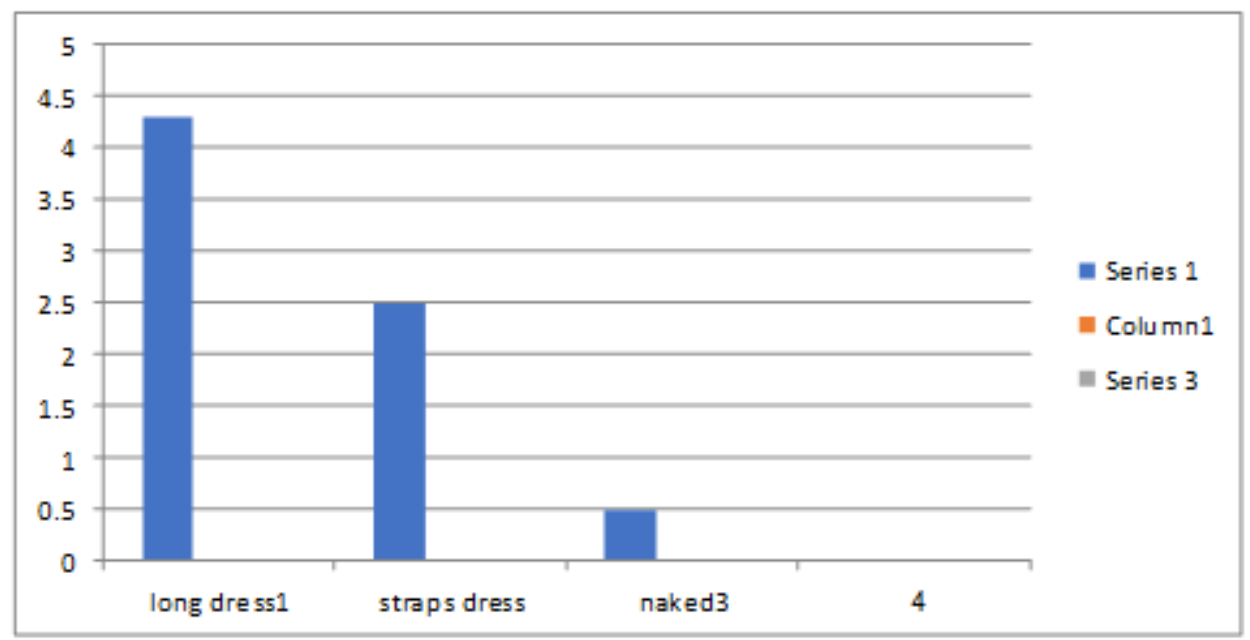

Chart.. 2. The clothes of goddess Anat

In chart 2 Anat appears wearing a long dress with two straps on shoulders. The tight tall dress is Egyptian without any foreign features.

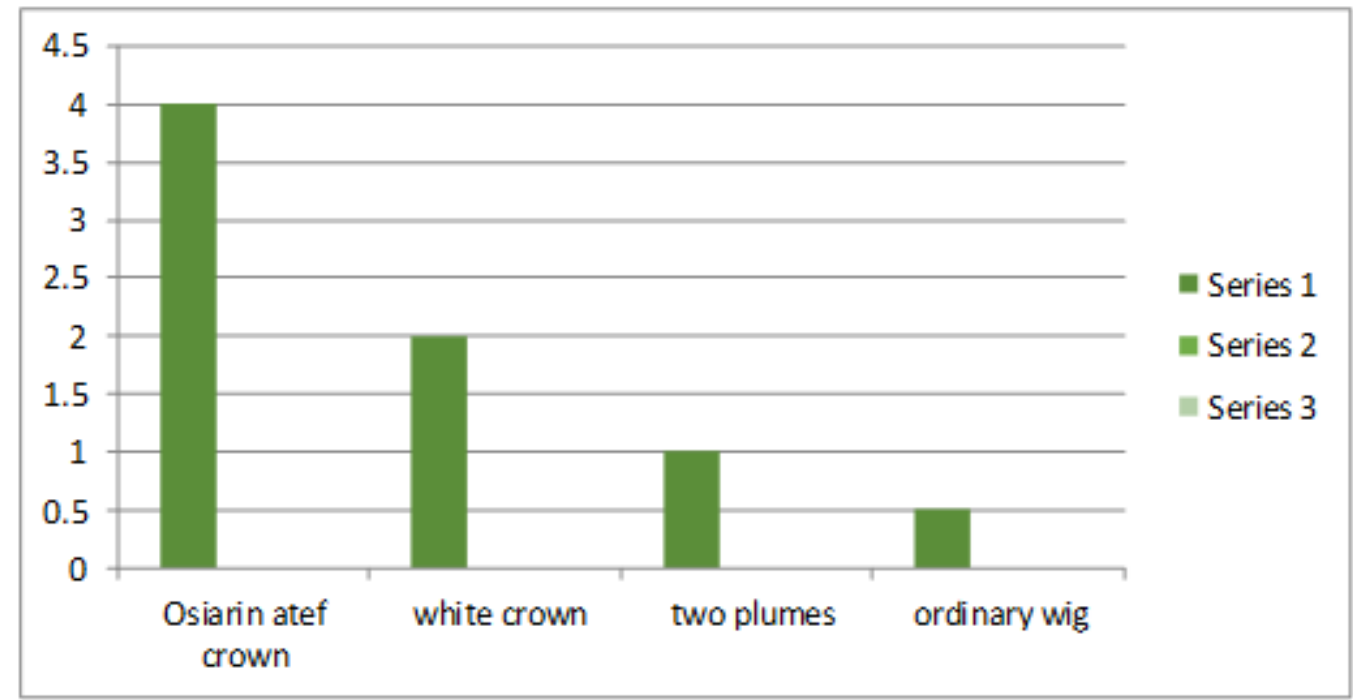

Chart. 3. The crowns of goddess Astarte

Chart 3 and 4 indicate the costumes of goddess Ashtart in her representations with king Ramses II. Chart 1 shows the crowns which Ashtart appears wearing. We can notice that the osiarian Atef crown occupied high pose among other crowns. It takes the Egyptian features without any Syrian additions. 


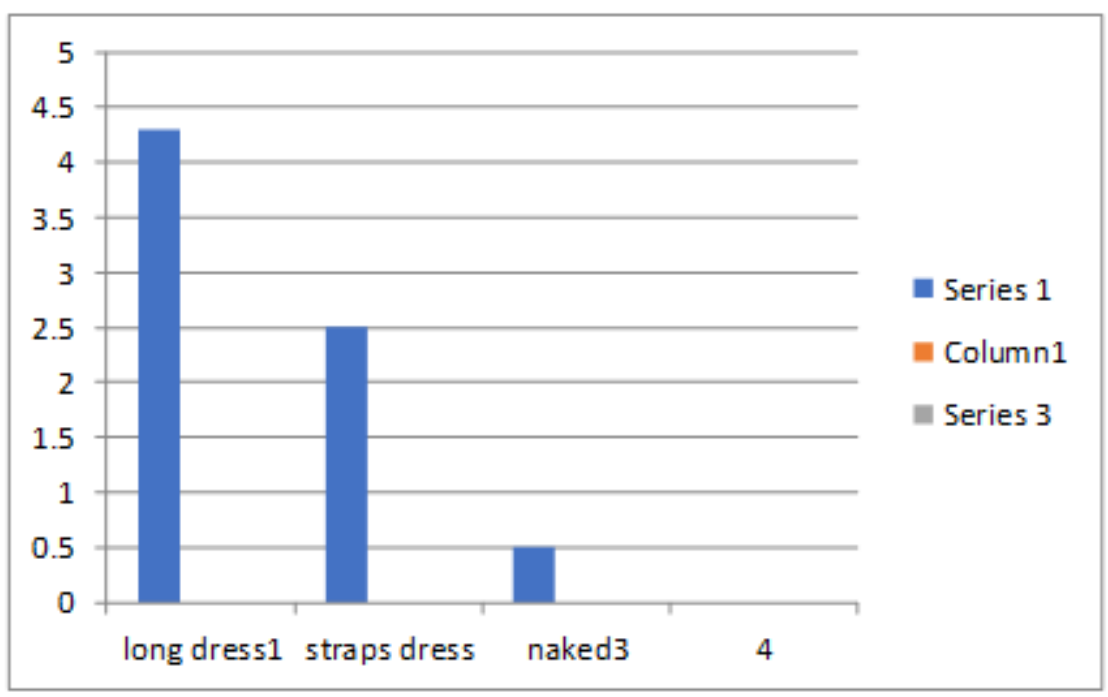

Chart.4. The clothing of goddess Astarte

In chart 4 Ashtart appears wearing a long dress with two straps on the shoulders. The tight tall dress is Egyptian without any foreign features

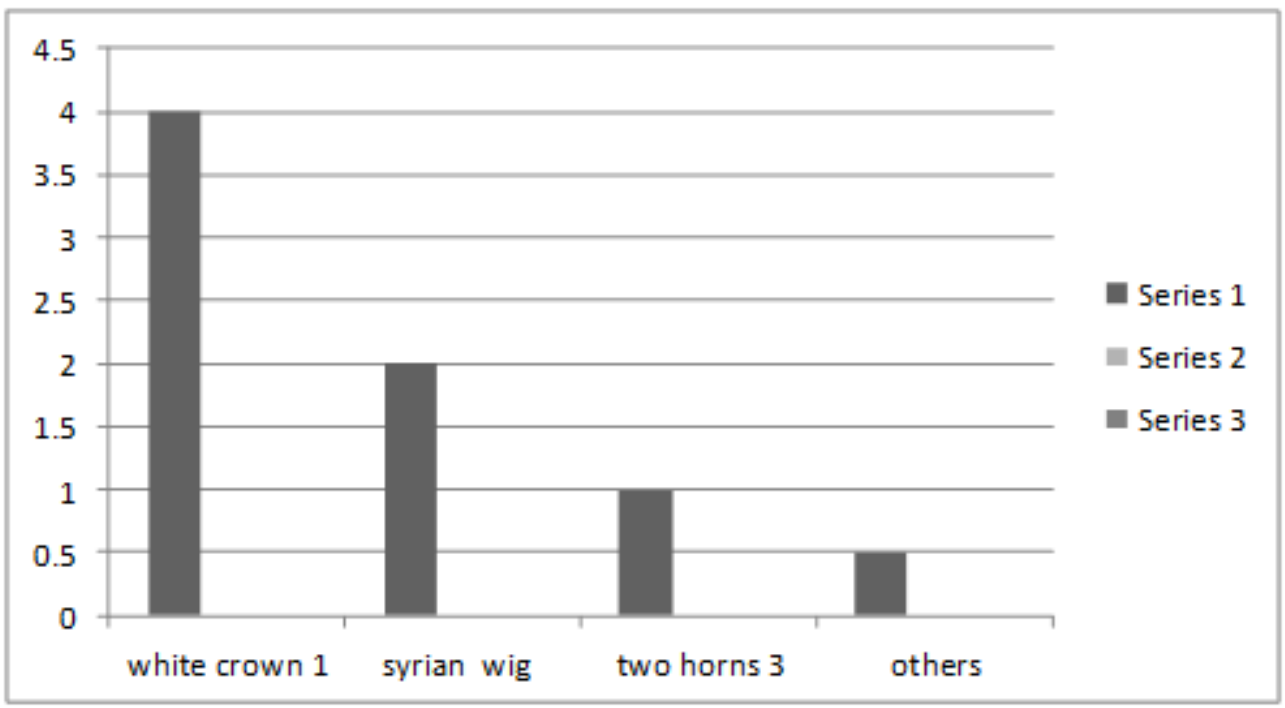

Chart.5. The crowns of god Baal

Chart 5 and 6 indicate the costumes of god Baal in his representations with king Ramses II. Chart 5 displays the crowns which Baal appears wearing. We can notice that the white crown which looks like the Egyptian one occupied high pose among other crowns. It takes the Egyptian features as conical crown with long streamer back. 


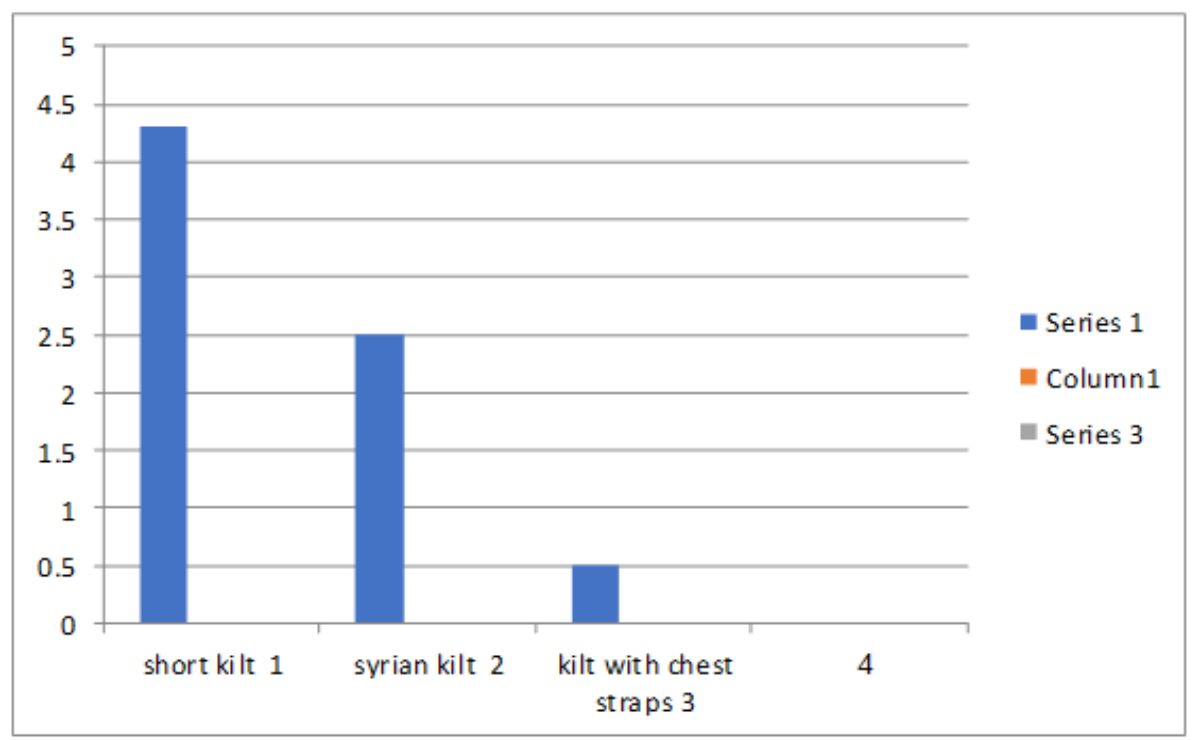

Chart. 6. The Costumes Of god Baal

Chart 6 displays the clothes of god Baal. It is clear that the short kilt takes the first place among other costumes. The artist depicted this kilt as in Egyptian tradition with Syrian tassels or endings fixed on the end of the kilt. It is not Egyptian fashion but the artist wanted to combine Egyptian style with Syrian style.

\section{Bibliographies}

- Albright, W. F., 1932. The North Canaanite Epic of Aleyan Bad and Mot. Jorma1 of the Palestine Oriental Society 12, p. 185-208;

- Albright, W.F. 1939. 'Astarte Plaques and Figurines from Tell Beit Mirsim', Mélanges Syriens offerts à Monsieur René Dussaud, Librairie Orientaliste Paul Geuthner, Paris, p. 107-120;

- Albright, W.F. 1939. 'Astarte Plaques and Figurines from Tell Beit Mirsim', Mélanges Syriens offerts à Monsieur René Dussaud, Librairie Orientaliste Paul Geuthner, Paris, p. 107-120;

- Albright, W.F. 1939. 'Astarte Plaques and Figurines from Tell Beit Mirsim', Mélanges Syriens offerts à Monsieur René Dussaud, Librairie Orientaliste Paul Geuthner, Paris, p. 107-120;

- Battenfield, J.R., 1988. Yahweh's Refutation of the Bad Myth Through the Actions of Elijah. In Israel's Apostasy and Restoration: Essays in Honor uf Roland K. Harrison., Edited by A. Gileadi., p. 19-37;

- Budde, D., Lexikon der Ägyptischen Götter und Golterhezeichnungen, Volume 1, Peeters Publishers, 2003;

- Cornelius, I., The Iconography of the Canaanite Gods Reshef and Ba'al. Late Bronze and Iron Age I Periods (c 1500 - 1000 BCE), Fribourg (Switzerland), University Press /Gottingen, Vandenhoeck \& Ruprecht 1994; Ithamar Gruenwald, Ilai Alon, Itamar Singer, Concepts of the Other in Near Eastern Religions, Brill, 1994;

- Cornelius, I., The Many Faces of the Goddess: The Iconography of the Syro-Palestinian Goddesses Anat, Astarte, Qedeshet, and Asherah c. 1500-1000 BCE. Academic Press Fribourg. Vandenhoeck \& Ruprecht. Gottingen, 2004, 
- Cornelius, Izak, Op. Cit. p.45; Lipinski, Edward, Egypto-Canaanite iconography of Reshef, Bacal, Horon, and Anat. Chronique d'Egypte 1996, pp. 251 -260.

- Dijkstra, M., 'The Myth of Astarte the Huntress, (KTU 1.92, New Fragments)'. UF 26, 1994, p. 113-126;

- Günter B., Heinz J. Thissen, Einführung in die Alteägyptische Literaturgeschichte, Volume 2, LIT Verlag Berlin-Hamburg-Münster, 2003.

- Helck, Wolfgang, 1966 Zum Auftreten fremder Götter in Ägypten. Oriens Antiques, p. 1

- J. M. Durand: SEL, 8 (1991), pp. 92; Hardly 'Sutean' as proposed by B. Margalit, The Ugaritic Poem of AQHT (BZ AW 182), Berlin 1989, pp. 337-40;

- Otto Kaiser, Die mythische Bedeutung des Meeres in Ägypten, Ugarit und Israel, Alfred Töpelmann, Berlin 1962.

- Roth, A.M., 'Father Earth, Mother Sky: Ancient Egyptian Beliefs about Conception and Fertility.' In Rautman (ed.), Reading the Body: Representations and Remains in the Archaeological Record, University of Pennsylvania Press. Philadelphia, 2000, p. 187-201

- Schneider, Thomas, Foreign Egypt: Egyptology and the concept of cultural appropriation. Ägypten und Levante 13, 2003.

- Stadelmann, R., 1967 Syrisch-Palastinensische Gottheiten in Ägypten. Probleme der Ägyptologie 5. Leiden: Brill;

- Stadelmann, R., 1967 Syrisch-Palastinensische Gottheiten in Ägypten. Probleme der Ägyptologie 5. Leiden: Brill;

- Stadelmann, Rainer, Syrisch-Palastinensische Gottheiten in Ägypten. Probleme der Ägyptologie 5. Leiden: Brill. 1967, p

- Tazawa, Keiko, 2009 Syro-Palestinian deities in New Kingdom Egypt: The hermeneutics of their existence. British Archaeological Reports International Series 1965.

- Tazawa, Keiko, Syro-Palestinian deities in New Kingdom Egypt: The hermeneutics of their existence. Oxford, 2009.

- Te Velde, H., Seth, God of Confusion: a study of his role in Egyptian mythology and religion, Brill Archive, 1977; Zeitschrift für Ethnologie, 3, 1871, p.139

- W.G. Lambert, Old Testament Mythology in its Ancient Near Eastern Context (VTS, 40), Leiden 1988, pp. 124-43, pl. 132.

- Wolfgang Helck: Die Beziechungen Ägyptens zu Vorderasien im 3. und 2. Jahrtausend v. Chr., (Ägyptologische Abhandlungen, Band 5) 2. Auflage, Harrassowitz, Wiesbaden 1971 


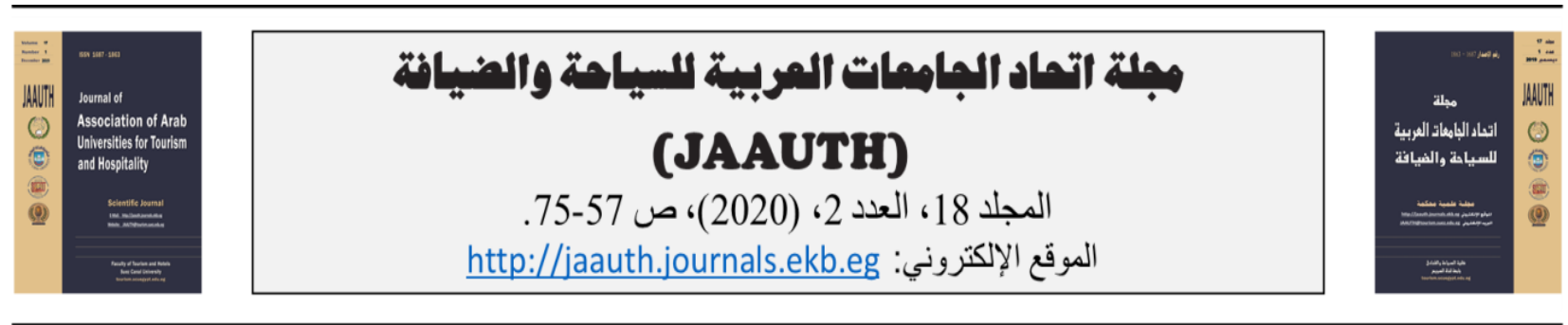

الملك رمسيس الثاني في مواجهة الآلهة الأسيوية: بعض الاعتبارات جديدة

إيفان إدوارد بولس

مدرس بقسم الإرشاد السياحي، أكاديمية الفراعنة للسياحة والفنادق، الهرم، الجيزة

\begin{tabular}{|c|c|}
\hline |lll| & \\
\hline 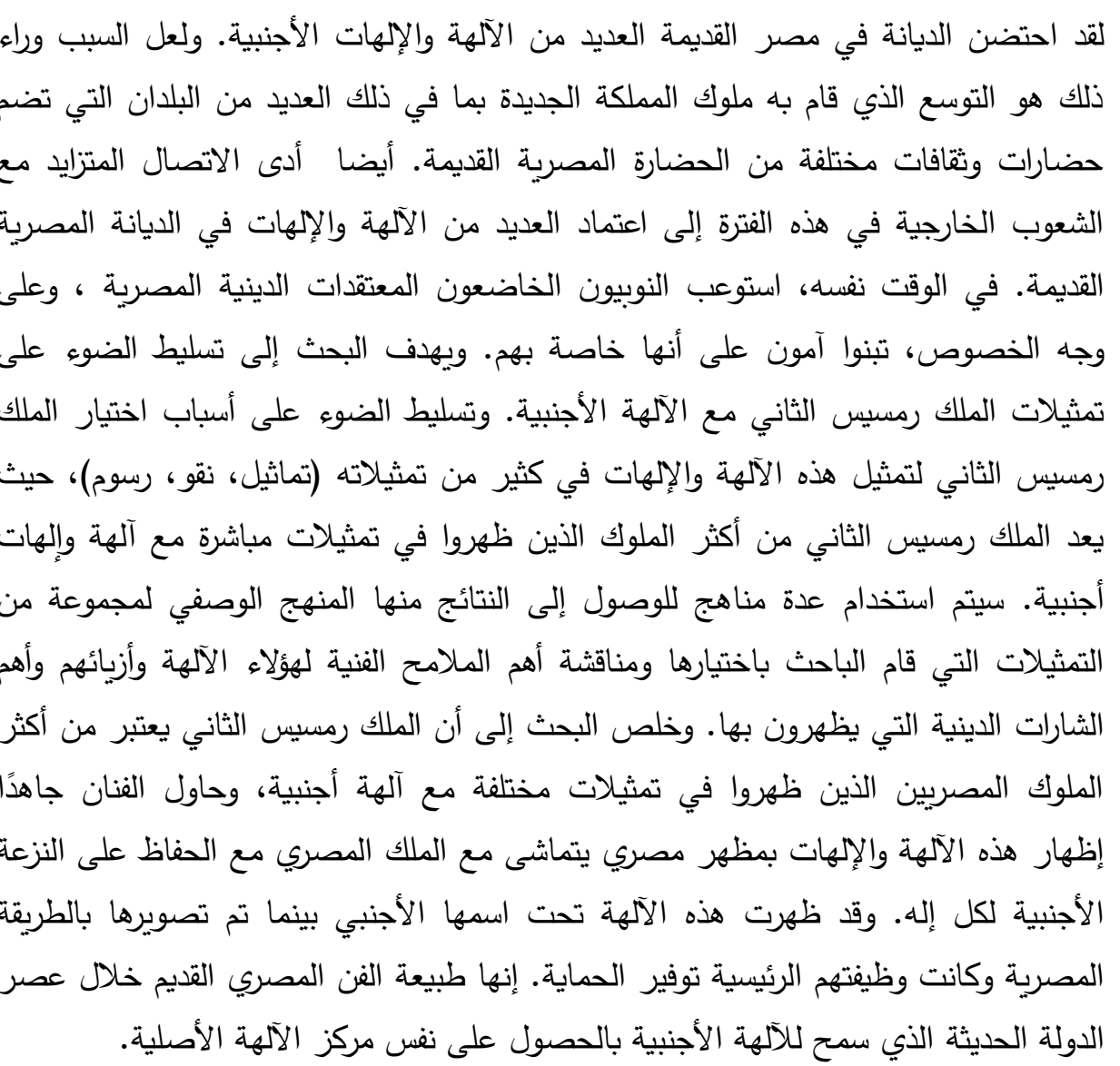 & 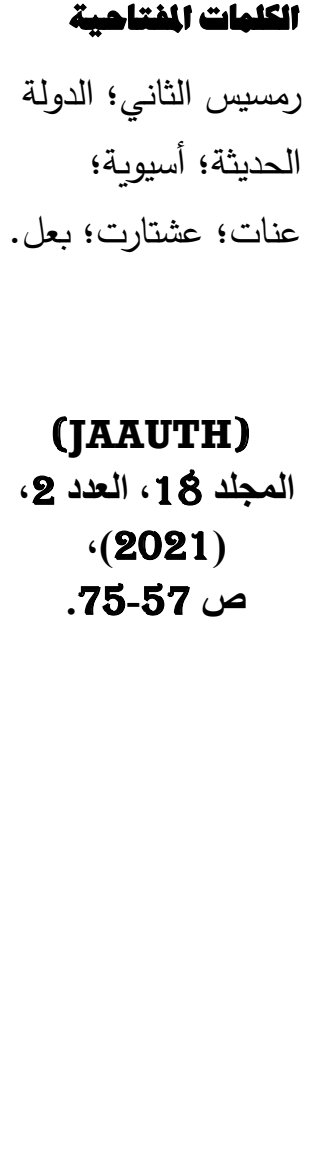 \\
\hline
\end{tabular}

